Jurnal Akuntansi dan Keuangan (JAK)

Volume 6, No. 2 Oktober Tahun 2021

Page: 257 - 269

http://ojs.uho.ac.id/index.php/jak-uho/issue/archive

e-ISSN: 2088-4656

\title{
PENGARUH SUMBER DAYA MANUSIA DAN SISTEM PENGENDALIAN INTERN TERHADAP KUALITAS INFORMASI LAPORAN KEUANGAN PEMERINTAH DAERAH DI KABUPATEN MUNA BARAT
}

\author{
Intihanah $^{1}$, Arifuddin $^{2}$, Faisal $^{3}$ \\ Jurusan Akuntansi Fakultas Ekonomi dan Bisnis Universitas Halu Oleo Kendari \\ Sulawesi Tenggara
}

\begin{abstract}
ABSTRAK
Penelitian bertujuan untuk menguji dan menjelaskan pengaruh sumber daya manusia dan pengendalian intern terhadap kualitas informasi laporan keuangan di kabupaten muna barat. Sampel pada penelitian ini berjumlah 51 orang pegawai bagian keuangan keuangan pada setiap OPD pemerintah Kabupaten Muna Barat. Metode pengumpulan data menggunakan kuesioner. Analisis data menggunakan metode analisis deskriptif dan analisis linear berganda. Hasil penelitian ini menunjukan bahwa: (1) sumber daya manusia berpengaruh positif signifikan terhadap kualitas informasi laporan keuangan di kabupaaten Muna Barat. (2) sistem pengendalian intern berpengaruh positif signifikan terhadap kualitas informasi laporan keuangan di kabupaaten Muna Barat. (3) sumber daya manusia dan sistem pengendalian intern secara simultan berpengaruh positif signifikan terhadap kualitas informasi laporan keuangan di kabupaaten Muna Barat.

Kata kunci: Sumber Daya Manusia, Sistem Pengendalian Intern, Kualitas Laporan Keuangan Daerah.
\end{abstract}

\begin{abstract}
This study aims to examine and explain the effect of human resources and internal control on the quality of financial report information in West Muna District. The sample in this study amounted to 51 employees of financial finance at each OPD of the West Muna Regency government. The data collection method used a questionnaire. Data analysis used descriptive analysis method and multiple linear analysis. The results of this study indicate that: (1) human resources have a significant positive effect on the quality of financial statement information in West Muna district. (2) the internal control system has a significant positive effect on the quality of financial report information in West Muna district. (3) human resources and the internal control system simultaneously have a significant positive effect on the quality of financial report information in West Muna district.

Keywords: Human Resources, Internal Control System, Quality of Regional Financial Reports.
\end{abstract}

\section{PENDAHULUAN}

Laporan Keuangan Pemerintah Daerah (LKPD) merupakan suatu bentuk laporan pertanggungjawaban pemerintah daerah terhadap tuntutan publik atas pengelolaan 
Jurnal Akuntansi dan Keuangan (JAK)

Volume 6, No. 2 Oktober Tahun 2021

Page: 257 - 269

http://ojs.uho.ac.id/index.php/jak-uho/issue/archive

e-ISSN: 2088-4656

keuangan daerah selama satu tahun anggaran. Dalam menyusun laporan keuangan,pemerintah daerah harus mengikuti Standar Akuntansi Pemerintahan (SAP) yang diatur dalam Peraturan Pemerintah No.71 Tahun 2010 yang merupakan perbaharuan dari Peraturan Pemerintah No. 24 Tahun 2005. Tujuan diberlakukannya hal tersebut adalah agar lebih accountable dan semakin diperlukannya peningkatan kualitas laporan keuangan.

Badan Pemeriksa Keuangan (BPK) selaku pemeriksa pengelolaan dan tanggung jawab keuangan lembaga negara, dalam menjalankan tugas dan wewenangnya dalam mengaudit laporan keuangan pemerintah makaselanjutnya disampaikan kepada DPR/DPRD dan masyarakat umum. Adapun komponen laporan keuangan yang disampaikan tersebut meliputi Laporan Realisasi Anggaran, Neraca, Laporan Arus Kas, dan Catatan atas Laporan Keuangan.

Laporan keuangan pemerintah dapat memenuhi kualitas yang dikehendaki haruslah memiliki keempat karakteristik kualitatif yang disyaratkan. Kualitatif laporan keuangan adalah ukuran-ukuran normatif yang perlu diwujudkan dalam informasi akuntansi sehingga dapat memenuhi tujuannya. Adapun karakteristik kualitatif laporan keuangan pemerintah sebagaimana disebutkan dalam Rerangka Konseptual Akuntansi Pemerintahan (Peraturan Pemerintah Nomor 71 tahun 2010) yakni:relevan, andal, dapat dibandingkan, dan dapat dipahami.

Apabila informasi yang terdapat di dalam Laporan Keuangan Pemerintah Daerah memenuhi kriteria karakteristik kualitatif laporan keuangan pemerintah seperti yang disyaratkan dalam Peraturan pamerintah Nomor 71 Tahun 2010, berarti pemerintah daerah mampu mewujudkan transparansi dan akuntabilitas dalam pengelolaan keuangan daerah.

Laporan keuangan yang dihasilkan oleh pemerintah daerah akan digunakan oleh beberapa pihak yang berkepentingan sebagai dasar untuk pengambilan keputusan. Oleh karena itu, informasi yang terdapat di dalam Laporan Keuangan Pemerintah Daerah (LKPD) harus bermanfaat dan sesuai dengan kebutuhan para pemakai. Informasi yang bermanfaat bagi para pemakai adalah informasi yangmempunyai kualitas, dapat mendukung pengambilan keputusan dan dapat dipahami oleh para pemakai. Oleh karena itu, pemerintah daerah wajib memperhatikan informasi yang disajikan dalam laporan keuangan pemerintah daerah untuk keperluan perencanaan, pengendalian, dan pengambilan keputusan.

Laporan keuangan pemerintah dapat memenuhi kualitas yang dikehendaki haruslah memiliki keempat karakteristik kualitatif diatas sebagai prasyarat normatif yang perlu diwujudkan dalam informasi akuntansi sehingga dapat memenuhi tujuannya. Kualitas laporan keuangan akan meningkatkan kualitas informasi yang disajikan dalam laporan keuangan. Para pengguna laporan keuangan yakin dalam mengambil keputusan karena didasarkan pada informasi yang telah dipersiapkan dengan baik, disetujui, dan diaudit secara transparan, dapat dipertanggungjawabkan dan berkualitas. Kualitas laporan keuangan adalah sejauh mana laporan keuangan menyajikan informasi yang 
Jurnal Akuntansi dan Keuangan (JAK)

Volume 6, No. 2 Oktober Tahun 2021

Page: 257 - 269

http://ojs.uho.ac.id/index.php/jak-uho/issue/archive

e-ISSN: 2088-4656

benar dan jujur. Hal ini berarti bahwa kualitas laporan keuangan menunjukkan konsep kualitas informasi dari laporan tersebut.

Laporan keuangan pemerintah dapat memenuhi kualitas yang dikehendaki haruslah memiliki keempat karakteristik kualitatif yang disyaratkan. Kualitatif laporan keuangan adalah ukuran-ukuran normatif yang perlu diwujudkan dalam informasi akuntansi sehingga dapat memenuhi tujuannya. Adapun karakteristik kualitatif laporan keuangan pemerintah sebagaimana disebutkan dalam Rerangka Konseptual Akuntansi Pemerintahan (Peraturan Pemerintah Nomor 71 tahun 2010) yakni:relevan, andal, dapat dibandingkan, dan dapat dipahami.

Laporan Kuangan Pemerintah Daerah (LKPD) disusun oleh Badan Pengelolah Keuangan dan Aset Daerah (BPKAD). Dimana BPKAD selain berperan menyusun laporan keungan konsolidasi dari tiap-tiap SKPD juga menyusun laporan kaungan sebagai SKPD sendiri. LKPD yang telah disusun dan dipertanggungjawabkan akan mendapat penilaian setiap tahunya berupa opini dari BPK. Terdapat 4 opini yang diberikan pemeriksa yaitu: Opini Wajar Tanpa Pengecuaalian (WTP), Opini Wajar Dengan Pengecualian (WDP), Opini Tidak Wajar (TP), dan Pernyataaan Menolak Memberi Opini atau Tidak Memberi Pendapat (TMT).

Pemerintah Kabupaten Muna Barat merupakan entitas yang juga diaudit oleh BPK terkait kinerja pengelolaan keuangannya. Hasil audit laporan keuangan Pemerintah Kabupaten Muna Barat yang mendapat opini Wajar Tanpa Pengecualian (WTP) pada tahun 2015-2019 , Peralihan metode pencatatan dari basis Kas ke basis Akrual sejak tahun 2015 adalah sebuah tantangan yang harus dihadapi untuk dapat mempertahankan opini Wajar Tanpa Pengecualian (WTP). Pencapaian ini merupakan prestasi pengelolaan keuangan sebab Pemerintah Daerah Muna Barat merupakan Daerah Otonomi Baru yang berdiri sejak tahun 2014 dan Pegawai Negeri Sipil yang menduduki jabatan bidang akuntansi di setiap Satuan Kerja Pemerintah Daerah (SKPD) tidak memiliki latar belakang keilmuan akuntansi. Adapun pengendalian internal seperti termaktub di LHP-LKPD Muna Barat Tahun Anggaran 2019 masih terdapat beberapa kelemahan seperti penataausahaan dan pengelolaan kas belum tertib, pengelolaan pajak bumi dan bangunan belum tertib, dan lain sebagainya.

Berdasarkan latar belakang dan rumusan masalah pada penelitian maka tujuan pada penelitian ini adalah Untuk mengetahui Sumber Daya Manusia dan pengendalian intern barpengaruh signifikan terhadap kualitas informasi laporan dan Untuk mengetahui Sumber Daya Manusia dan Pengendalian Intern secara simultan berpengaruh terhadap kualitas informasi laporan keuangan Pemerintah Daerah di Kabupaten Muna Barat.

\section{LANDASAN TEORI DAN HIPOTESIS}

\section{Sumber Daya Manusia}

Sutrisno (2009:58) menyatakan bahwa SDM merupakan satu-satunya sumber daya yang memiliki akal perasaan, keinginan, keterampilan, pengetahuaan, dorongan, 
Jurnal Akuntansi dan Keuangan (JAK)

Volume 6, No. 2 Oktober Tahun 2021

Page: 257 - 269

http://ojs.uho.ac.id/index.php/jak-uho/issue/archive

e-ISSN: 2088-4656

daya dan kerja (rasio, rasa, dan karya). Semua potensi SDM tersebut berpengaruh terhadap upaya organisasi dalam mencapai tujuan. betapapun majunya teknologi, perkembangan informasi dan tersedianya modal dan memadainya bahan, jika tanpa SDM sulit untuk organisasi tersebut mencapai tujuaanya.

Menurut Muins (2000:40), ada tiga jenis kompetensi sumber daya manusia yaitu "kompetensi profesi, kompetensi individu dan kompetensi sosial". Kompetensi profesi merupakan kamampuan untuk menguasai keterampilan/keahlian pada bidang tertentu, sehingga tenaga kerja mampu bekerja lebih cepat, tepat dan bertanggung jawab

Menurut Prayitno dan Suprapto (BKN, 2002:110), Standar kopetensi mencangkup tiga hal, yaitu disingkat dengan KSA: Pengetahuan (knowledge), yaitu fakta dan angka dibalik aspek teknis, Ketermpilan (skill), yaitu kempuan untuk menunjukan tugas pada tingkat kriteria yang dapat diterima secara terus menerus dengan kegiatan yang paling sedikit, Sikap (attitude), yaitu yang ditunjukan kepada pelanggang dan orang lain bahawa yang bersangkutan mampu berada dalam lingkungan kerjanya.

\section{Sistem Pengendalian Intern}

Pengendalian intern didefinisikan sebagai suatu proses yang dipengaruhi oleh sumber daya manusia dan sistem teknologi informasi yang dirancang untuk membantu organisasi mencapai suatu tujuan tertentu. Pengendalian intern merupakan suatu cara untuk mengarahkan, mengawasi, dan mengukur sumber daya suatu organisasi, serta berperan penting dalam pencegahan dan pendeteksian penggelapan atau fraud (Afriyanti, 2011)

Pengendalian intern yang didefinisikan oleh COSO (2013) adalah: "Pengendalian internal adalah sebuah proses, yang dilakukan oleh dewan direksi, manajemen, dan personel entitas lainnya, yang dirancang untuk memberikan jaminan yang wajar terkait pencapaian tujuan yang berkaitn dengan operasi pelaporan dan kepatuhan.

Sistem pengendalian intern bukan hal baru dalam pemerintahan. Petrovits et al. (2011) menyatakan Pengendalian internal secara luas didefinisikan sebagai proses yang dilakukan oleh manajemen untuk memberikan jaminan yang wajar mengenai pencapaian operasi yang efektif dan efisien, pelaporan keuangan yang andal, dan kepatuhan terhadap hukum dan peraturan

SPI merupakan kegiatan pengendalian terutama atas pengelolaan sistem informasi yang bertujuan untuk memastikan akurasi dan kelengkapan informasi. Kegiatan pengendalian atas pengelolaan informasi meliputi: Pengendalian umum, Pengendalian ini meliputi pengamanan sistem informasi, pengendalian atas akses, pengendalian atas pengembangan dan perubahan perangkatlunak aplikasi, pengendalian atas perangkat lunak sistem, pemisaan tugas,dan kontinuitas pelayanan dan Pengendalian aplikasi, Pengendalian ini meliputi pengendalian otorisasi, pengendalian kelengkapan, pengendalian akurasi, dan pengendalian terhadap keandalan pemrosesan dan file data. 
Jurnal Akuntansi dan Keuangan (JAK)

Volume 6, No. 2 Oktober Tahun 2021

Page: 257 - 269

http://ojs.uho.ac.id/index.php/jak-uho/issue/archive

e-ISSN: 2088-4656

SAS mendefinisikan lima komponen pengendalian intern yang saling berkaitan pada pernyataan COSO (2013) yaitu: Lingkungan pengendalian, Penilaian risiko, Aktivitas pengendalian, Informasi dan komunikasi dan Pengawasan.

\section{Kualitas Informasi laporan keuangan pemerintah Daerah}

Akuntansi keuangan sektor publik terkait dengan tujuan dihasilkannya laporan keuangan pemerintah (LKP). LKP adalah asersi dari pihak manajemen pemerintah yang menyajikan informasi yang berguna untuk pengambilan keputusan dan untuk menunjukan akuntabiliitas entitas pelaporan atas sumber daya yang dipercayakan kepadanya. Laporan keuangan terutama untuk membandingkan realisasi pendapatan, belanja, transfer, dan pembiayaan dengan anggaran yang telah ditetapkan, menilai kondisi keuangan, mengevaluasi efektifitas dan efisiensi suatu etintas pelaporan, dan membantu menentukaan ketaatanya terhadap peraturan perundang-undangan. Adapun laporan keuangan pokok berbasis kas menuju akrual yang harus disusun oleh pemerintah sebagaimana tercantum dalam peraturan pemerintah Nomor 71 Tahun 2010 tentang standar akuntansi pemerintahan, Lampiran II, meliputi: (1) Realisasi Anggaran, (2) Neraca, (3) Laporan Arus Kas, dan (4) Catatan atas Laporan Keuangan.

Standar Akuntasi pemerintahan (SAP) yang terkandung dalam peraturan pemerintah No. 71 Tahun 2010 Mengadopsi karateristik kualitatif primer sebagaimana tercantum SFAC No. 2. Hanya saja SAP menekankan pada empat prasyarat normatif yakni:

1. Relevan, Laporan keuangan bisa dikatakan relevan apabila informasi yang termuat di dalamnya dapat mempengaruhi keputusan pengguna dengan membantu mereka mengevaluasi peristiwa masa lalu atau masa kini dan memprediksi masa depan serta menegaskan atau mengoreksi hasil evaluasi mereka di masa lalu,

2. Andal, Informasi Dalam laporan keuangan bebas dari pengertian yang menyesatkan dan kesalahan material, menyajikan setiap fakta secara jujur, serta dapat diverifikasi.

3. dapat dibandingkan, Informasi yang termuat dalam laporan keuangan akan lebih berguna jika dapat dibandingkan dengan laporan keuangan periode Sebelumnya atau laporan keuangan entitas pelaporan lain pada umumnya. Perbandingan dapat dilakukan secara internal dan eksternal.

4. dapat dipahami, Informasi yang disajikan dalam laporan keuangan dapat dipahami oleh pengguna dan dinyatakan dalam bentuk serta istilah yang disesuaikan dengan batas pemahaman para pengguna. Untuk itu, pengguna diasumsikan memiliki pengetahuan yang memadai atas kegiatan dan lingkungan operasi entitas pelaporan, serta adanya kemauan pengguna untuk mempelajari informasi yang dimaksud.

\section{Hipotesis}

Berdasarkan penjelasan diatas, maka hipotesis diajukan sebagai berikut:

H1: Kompetensi sumber daya manusia berpengaruh signifikan terhadap kualitas informasi laporan keuangan.

$\mathrm{H} 2$ : Sistem pengendalian intern berpengaruh signifikan terhadap kualitas informasi laporan keuangan. 
Jurnal Akuntansi dan Keuangan (JAK)

Volume 6, No. 2 Oktober Tahun 2021

Page: 257 - 269

http://ojs.uho.ac.id/index.php/jak-uho/issue/archive

e-ISSN: 2088-4656

H3: kopetensi Sumber daya manusia dan pengendalian intern berpengaruh signifikan secara simultan terhadap kualitas informasi laporan keuangan.

\section{METODE PENELITIAN}

Objek penelitian ini adalah Kualitas Informasi Keuangan Daerah sebagai variabel Dependen (Y), Kompetensi Sumber Daya Manusia (X1), Pengendalian Intern (X2) sebagai variabel Independen, lokasi penelitian adalah lingkup Pemerintah Kabupaten Muna Barat.

Populasi adalah wilayah generalisasi yang terdiri atas objek/subjek yang mempunyai kualitas dan karakteristik tertentu yang ditetapkan oleh peneliti untuk dipelajari dan kemudian ditarik kesimpulannya Sugiyono (2017:80). Populasi dalam penelitian adalah pegawai di bidang keuangan yang ada disetiap OPD di Pemerintah Kabupaten Muna Barat.

Jenis data yang digunakan dalam penelitian ini adalah data kuantitatif dan data kualitatif. data kualitatif berupa uraian penjelasan dari variabel dan pernyataan dalam kuesioner yang akan diklasifikasikan dalam kategori menggunakan skala Likert. Data kuantitatif dalam penelitian ini adalah jawaban responden atas pertanyaan kuesioner yang diukur menggunakan skor dari skala Likert.

Sumber data yang digunakan dalam penelitian ini berupa data primer dan sekunder. Data primer dalam penelitian ini adalah data yang diperoleh secara langsung dari responden dengan menggunakan kuesioner yang disusun berdasarkan variabelvariabel yang diteliti. Data sekunder dalam penelitian ini adalah data yang diperoleh dari luar data primer yang mendukung dalam penelitian.

Metode pengumpulan data yang digunakan dalam penelitian adalah: Kuesioner, dilakukan dengan menyebarkan kuisioner yang memuat pernyataan-pernyataan yang berkaitan dengan variabel penelitian. Wawancara, merupakan proses untuk memperoleh keterangan untuk mencapai tujuan penelitian yang dilakukan melalui kegiatan komunikasi verbal berupa percakapan. Studi kepustakaan yaitu mempelajari buku-buku literatur dan bacaan-bacaan lain yang dapat membantu dalam pemecahan masalah.

Metode analisis data yang digunakan Metode analisis data yang digunakan dalam penelitian ini yaitu sebagai berikut:

1. Analisis Statistika Deskriptif digunakan untuk menganalisis data dengan cara mendeskripsikan atau menggambarkan data yang telah terkumpul sebagaimana adanya tanpa bermaksud membuat kesimpulan yang berlaku untuk umum atau generalisasi Sugiyono (2017:147). Metode analisis deskriptif yang dilakukan dalam penelitian ini adalah analisis deskriptif persentase, dengan skala yang digunakan adalah Skala Likert yang mempunyai skor 1 sampai 5. Nilai rata-rata pembobotan atau nilai skor jawaban responden yang di peroleh diklasifikasikan ke dalam rentang skala kategori nilai yang disajikan sebagai berikut : 
Jurnal Akuntansi dan Keuangan (JAK)

Volume 6, No. 2 Oktober Tahun 2021

Page: 257 - 269

http://ojs.uho.ac.id/index.php/jak-uho/issue/archive

e-ISSN: 2088-4656

Tabel 1

Penentuan Kategori Rata-rata Skor Pernyataan Responden

\begin{tabular}{|l|c|c|}
\hline No. & $\begin{array}{c}\text { Nilai rata-rata } \\
\text { skor jawaban }\end{array}$ & Makna Kategori/Interpretasi \\
\hline 1. & $1-1,8$ & Sangat Rendah/Tidak Baik \\
\hline 2. & $1,8>-2,6$ & Rendah/Kurang Baik \\
\hline 3. & $2,6>-3,4$ & Cukup Tinggi/Cukup Baik \\
\hline 4. & $3,4>-4,2$ & Tinggi/Baik \\
\hline 5. & $4,22>$ & Sangat Tinggi/Sangat Baik \\
\hline
\end{tabular}

2. Analisis regresi linier berganda adalah analisis yang digunakan peneliti, bila bermaksud meramalkan bagaimana keadaan (naik turunnya) variabel dependen (kriterium), bila dua atau lebih variabel independen sebagai faktor prediktor dimanipulasi (dinaik turunkan nilainya) Sugiyono (2010).

$$
Y=\alpha+B 1 X 1+B 2 X 2+e
$$

Keterangan :

$\mathrm{Y}=$ kualitas informasi laporan keuangan

$\alpha=$ nilai konstanta

$\beta 1, \beta 2=$ Koefisien masing-masing Variabel

$\mathrm{X} 1$ = Sumber Daya Manusia

$\mathrm{X} 2=$ Pengendalian intern

e $=$ Error Term, yaitu tingkat kesalahan penduga dalam penelitian

pengujian hipotesis melalui uji $\mathrm{F}$, uji statistik $\mathrm{T}$ dan uji koefisien determinasi.

Pengujian dapat dilakukan setelah model regresi bebas dari gejala-gejala asumsi klasik. Pengujian asumsi klasik yang dilakukan dalam penelitian ini meliputi uji normalitas, uji Heteroskedastisitas dan Uji Heteroskedastisitas.

\section{HASIL DAN PEMBAHASAN}

\section{Hasil penelitian}

\section{Analisis Deskriptif}

Analisis deskriptif merupakan analisis yang didasarkan pada hasil jawaban yang diperoleh dari penilaian atas pertanyaan-pertanyaan yang diajukan oleh penulis.

Hasil analisis deskriptif menunjukan bahwa variabel sumber daya manusia (SDM) memiliki nilai rata-rata (mean) sebesar 4,36 dan nilai indikator terkecil nilai 4,34 dan nilai rata-rata indikator terbesar 4,30. Variabel sistem Pengendalian Intern (SPI) memiliki nilai rata-rata (mean) sebesar 4,17 dan nilai indikator terkecil nilai 4,34 dan nilai rata-rata indikator terbesar 4,05 dan Variabel Kualitas Informasi laporan Keuangan memiliki nilai rata-rata (mean) sebesar 4,23 dan nilai indikator terkecil nilai 4,15 dan nilai rata-rata indikator terbesar 4,29. 
Jurnal Akuntansi dan Keuangan (JAK)

Volume 6, No. 2 Oktober Tahun 2021

Page: 257 - 269

http://ojs.uho.ac.id/index.php/jak-uho/issue/archive

e-ISSN: 2088-4656

\section{Uji Kualitas Data}

Hasil pengujian validitas menunjukan bahwa pernyataan dari semua variabel bebas ataupun variabel terikat menunjukan hasil yang valid karena nilai signifikansinya lebih kecil dari 0,05 sehingga dinyatakan bahwa semua variabel penelitian telah valid. Serta hasil pengujian reabilitas menunjukan bahwa dari semua variabel bebas atapun variabel terikat menunjukan hasil yang reliebel karena nilai koefisien kolerasi dari hasil cronbach alpha > 0,60 sehingga dinyatakan bahwa semua variabel penelitian telah reliebel.

\section{Uji Asumsi Klasik}

1) Uji normatif bertujuan untuk menguji apakah dalam model regresi variabel dependen (terikat) dan variabel independen (bebas) mempunyai distribusi normal. Model regresi yang baik adalah data distribusi normal atau mendekati normal. Deteksi normalitas dapat dilakukan dengan metode grafik. Hasil uji metode grafik dengan melihat penyebaran titik pada sumbu diagonal dari grafik. Selanjutnya dapat pula dibuktikan dengan Kolmogorov Smirnov Test. Dasar pengambilan keputusan jika nilai $\mathrm{p}$ robabilitas atau Asymp. Sig (2-tailed) $\geq \alpha=0.05$ (taraf signifikan yang ditetapkan peneliti 95\%).

Tabel 1

\begin{tabular}{|l|c|c|}
\hline \multicolumn{1}{|c|}{ Item } & Sumber Daya Manusia & Pengendalian Intern \\
\hline Kolmogorov-Smirnov Z & 1,273 & 1,352 \\
\hline Asymp. Sig. (2-tailed) &, 078 &, 052 \\
\hline
\end{tabular}

Sumber: Hasil olahan data primer, Tahun 2021

Hasil analisis diperoleh bahwa nilai Kolmogorov Smirnov (K-S) variable bebas sumber daya manusia dan pengendalian intern senilai 1,273 dan 1,352. Nilai Asymp.Sig (2-tailed) variable bebas sumber daya manusia dan pengendalian intern sebesar 0,078 dan 0,052. Hasil tersebut mengindikasikan bahwa model persamaan regresi tersebut berdistribusi normal karena nilai Asymp. Sig (2-tailed) lebih besar dari nilai $\alpha=0,05$.

2) Uji Multikolinieritas. Deteksi adanya multikolnearitas dapat dilakukan dengan cara melihat besarnya Variance Inflation Factor (VIF) dan toleransi. Asumsi klasik model regresi adalah tidak boleh terdapat multikolinieritas di antara variabel-variabel bebas didalam model. Deteksi adanya multikolnearitas dapat dilakukan dengan cara melihat besarnya Variance Inflation Factor (VIF) dan toleransi. Kriteria suatu model regresi yang bebas dari multikolinearitas apabila mempunyai nilai VIF tidak boleh besaran nilai toleransi lebih dari cut of point $\leq 5$ (Imam Ghozali. 2010). 
Jurnal Akuntansi dan Keuangan (JAK)

Volume 6, No. 2 Oktober Tahun 2021

Page: 257 - 269

http://ojs.uho.ac.id/index.php/jak-uho/issue/archive

e-ISSN: 2088-4656

Tabel 2

\begin{tabular}{|l|c|c|c|}
\hline \multirow{2}{*}{ Variabel Bebas } & \multicolumn{2}{|c|}{ Collinearity Statistics } & Cut of Point \\
\cline { 2 - 3 } & Toleransi & VIF & $\begin{array}{c}\leq \mathbf{5} \text { (VIF mendekati 1) } \\
\text { (Imam Ghozali. 2010) }\end{array}$ \\
\hline Sumber Daya Manusia &, 906 & 1,104 & $\begin{array}{c}\leq \mathbf{5} \text { (VIF mendekati 1) } \\
\text { (Imam Ghozali. 2010) }\end{array}$ \\
\hline Pengendalian Intern &, 906 & 1,104 & \multicolumn{2}{|c|}{}
\end{tabular}

Sumber: Hasil olahan data primer, Tahun 2021

Hasil Variance Inflation Factor (VIF) mendekati angka 1 dan nilai toleransi dari variabel bebas kompensasi financial dan penilaian prestasi kerja dengan cut of point $\leq 5$. Dapat disimpulkan tidak terjadi gejala multikolinearitas dalam modelanalisis regresi yang digunakan dalam penelitian ini.

3) Uji Heteroskedastisitas.

Terjadinya heteroskedastisitas ditunjukkan dengan adanya ketidaksamaan varian nilai residualnya antara variabel bebas yang dapat dideteksi melalui perhitungan uji koefisien korelasi Rank Spearman. Hasil uji koefisien korelasi Rank Spearman yang mengkorelasikan antara nilai absolute residual dengan setiap variabel bebas.

Tabel 3

\begin{tabular}{|l|c|c|c|}
\hline \multicolumn{1}{|c|}{ Variabel Bebas } & $\begin{array}{c}\text { Koefisien } \\
\text { Korelasi }\end{array}$ & Probabilitas & Hasil \\
\hline Sumber Daya Manusia & 0.000 & 1.000 & Homoskedastisitas \\
\hline Pengendalian Intern & 0.000 & 1.000 & Homoskedastisitas \\
\hline
\end{tabular}

Sumber: Hasil olahan data primer, 2021

Pada Tabel di atas menunjukkan bahwa koefisien korelasi dari variabel bebas kompensasi financial dan diferensiasi produk adalah lebih besar dari $\alpha=0.05$ yang berarti model analisis regresi yang digunakan dalam penelitian ini tidak terjadi heteroskedastisitas.

\section{Uji Hipotesis}

Pengujian hipotesis dan koefisien jalur pengaruh parsial dan simultan antara variabel sumber daya manusia dan pengendalian intern terhadap kualitas informasi laporan keuangan. Hasil analisis pengujian nilai koefisien jalur, titik kritis (t-statistik) dan $p$-value.

\section{Tabel 4}

\begin{tabular}{|c|l|c|c|c|c|c|}
\hline \multicolumn{2}{|c|}{ Pengaruh Parsial } & $\begin{array}{c}\text { Uns. } \\
\text { Coefficient }\end{array}$ & t-value & Sig. t & \multicolumn{2}{c|}{ Hasil } \\
\hline H1. & $\begin{array}{l}\text { Sumber Daya manusia } \rightarrow \\
\text { Kualitas Informasi } \\
\text { Keuangan }\end{array}$ & 0,358 & 2,935 &, 005 & $\geq \alpha=0.05$ & Diterima \\
\hline H2. & $\begin{array}{l}\text { Pengendalian intern } \rightarrow \\
\text { Kualitas Informasi } \\
\text { Keuangan }\end{array}$ & 0,416 & 3,404 &, 001 & $\geq \alpha=0.05$ & Diterima \\
\hline
\end{tabular}


Jurnal Akuntansi dan Keuangan (JAK)

Volume 6, No. 2 Oktober Tahun 2021

Page: 257 - 269

http://ojs.uho.ac.id/index.php/jak-uho/issue/archive

e-ISSN: 2088-4656

\begin{tabular}{|l|l|c|c|c|c|}
\hline \multicolumn{2}{|c|}{ Pengaruh Simultan } & F-value & Sig. t & \multicolumn{2}{c|}{ Hasil } \\
\hline H3. & $\begin{array}{l}\text { Sumber Daya Manusia dan Pengendalian } \\
\text { Intern } \rightarrow \text { Kualitas Informasi Keuangan }\end{array}$ & 14,527 &, 000 & $\geq \alpha=0.05$ & Diterima \\
\hline \multicolumn{3}{|c|}{ Sumber: Hasil olahan data Tahun 2021 }
\end{tabular}

Sumber: Hasil olahan data, Tahun 2021

Pada tabel di atas menunjukkan bahwa koefisien korelasi dari variabel bebas kompensasi financial dan diferensiasi produk adalah lebih besar dari $\alpha=0.05$ yang berarti model analisis regresi yang digunakan dalam penelitian ini tidak terjadi heteroskedastisitas.

Hasil pengujian pengaruh sumber daya manusia terhadap kualitas informasi laporan keuangan dapat dibuktikan dengan nilai estimate koefisien jalur sebesar 0,358 dengan arah positif. Koefisien jalur bertanda positif memiliki arti pengaruh antara sumber daya manusia terhadap kualitas informasi keuangan adalah searah. Kemudian dapat pula dibuktikan dengan nilai sig. $t$ sebesar $0,005<\alpha=0,05$. Hasil pengujian membuktikan bahwa sumber daya manusia berpengaruh positif dan signifikan terhadap kualitas informasi keuangan. Artinya semakin baik kualitas sumber daya manusia, informasi keuangan pada Pemeritah Daerah Kabupaten Muna Barat semakin berkualitas. Hal tersebut menjadikan hipotesis pertama yang diajukkan dalam penelitian ini dapat diterima atau didukung oleh fakta.

Hasil pengujian pengaruh pengendalian intern terhadap kualitas informasi laporan keuangan dapat dibuktikan dengan nilai estimate koefisien jalur sebesar 0,416 dengan arah positif. Koefisien jalur bertanda positif memiliki arti pengaruh antara pengendalian intern terhadap kualitas informasi keuangan adalah searah. Kemudian dapat pula dibuktikan dengan nilai sig. $t$ sebesar $0,001<\alpha=0,05$. Hasil pengujian membuktikan bahwa pengendalian intern berpengaruh positif dan signifikan terhadap kualitas informasi keuangan. Artinya semakin baik penerapan pengendalian intern, informasi keuangan pada Pemeritah Daerah Kabupaten Muna Barat semakin berkualitas. Hal tersebut menjadikan hipotesis kedua yang diajukkan dalam penelitian ini dapat diterima atau didukung oleh fakta.

Hasil pengujian pengaruh sumber daya manusia dan pengendalian intern terhadap kualitas informasi keuangan dapat dibuktikan dengan nilai $F$ sebesar 14,527 dengan arah positif. Koefisien jalur bertanda positif memiliki arti pengaruh antara sumber daya manusia dan pengendalian intern terhadap kualitas informasi keuangan adalah searah. Kemudian dapat pula dibuktikan dengan nilai sig. $t$ sebesar $0,000<\alpha=0,05$. Hasil pengujian membuktikan bahwa sumber daya manusia dan pengendalian intern secara bersama-sama berpengaruh positif dan signifikan terhadap kualitas informasi laporan keuangan. Artinya semakin baik kualitas sumber daya manusia dan penerapan pengendalian intern, informasi laporan keuangan pada Pemeritah Daerah Kabupaten Muna Barat semakin berkualitas. Hal tersebut menjadikan hipotesis ketiga yang diajukkan dalam penelitian ini dapat diterima atau didukung oleh fakta. 
Jurnal Akuntansi dan Keuangan (JAK)

Volume 6, No. 2 Oktober Tahun 2021

Page: 257 - 269

http://ojs.uho.ac.id/index.php/jak-uho/issue/archive

e-ISSN: 2088-4656

\section{Pembahasan}

\section{Pengaruh Sumber Daya Manusia terhadap Kualitas Informasi Laporan Keuangan}

Hasil pengujian hipotesis menunjukkan bahwa X2 memiliki nilai sig. $=0.005<$ 0,05 . Artinya sistem pengendalian intern memiliki pengaruh yang signifikan terhadap Kualitas Laporan Keuangan.

Melihat nilai mean dari hasil frekuensi jawaban responden, indikator yang paling dominan adalah indikator pengetahuan. Hal ini menunjukkan bahwa semakin tinggi pengetahuan yang dimiliki pegawai di bidang keuangan maka akan meningkatkan kualitas sumber daya manusia. Selain itu perlu didukung dengan keterampilan dan sikap yang baik yang dimiliki oleh pegawai di bidang keuangan disetiap SKPD.

Hasil penelitian ini sejalan dengan penelitian Sukmaninggrum dan Harto (2011), Mahaputra dan Putra (2014), dan Ratnaningsih (2017), menemukan bahwa sumber daya manusia berpengaruh positif dan signifikan terhadap kualitas informasi keuangan.

\section{Pengaruh Pengendalian Intern terhadap Kualitas Informasi Laporan Keuangan}

Hasil pengujian hipotesis menunjukkan bahwa X2 memiliki nilai sig. $=0.001<$ 0,05 . Artinya sistem pengendalian intern memiliki pengaruh yang signifikan terhadap Kualitas Laporan Keuangan.

Melihat nilai mean dari hasil frekuensi jawaban responden, indikator yang paling dominan adalah indikator pengawasan. Hal ini menunjukkan bahwa sistem pengendalian intern telah menerapkan pengawasan dengan kode etik serta penetuan batas dan toleransi yang baik. Selain itu,penilaian risiko dan kegiatan pengendalian dalam sistem pengendalian intern juga berperan dalam rangka penyusunan LKPD yang baik, tentunya hal ini juga perlu didukung dengan infromasi dan komunikasi serta lingkuan pengendalian yang baik dalam sistem pengendalian intern oleh pegawai di bidang keuangan di SKPD.

Hasil penelitian ini juga sejalan dengan penelitian Sukmaninggrum dan Harto (2011), Mahaputra dan Putra (2014), dan Ratnaningsih (2017), menemukan bahwa pengendalian intern berpengaruh positif dan signifikan terhadap kualitas informasi keuangan.

\section{Sumber Daya Manusia dan Pengendalian Intern Berpengaruh Signifikan Terhadap Kualitas Informasi Laporan Keuangan}

Hasil pengujian hipotesis menunjukkan bahwa $\mathrm{X} 1$ dan $\mathrm{X} 2$ memiliki nilai sig. $=$ 0,000. Artinya kualitas sumber daya manusia dan sistem pengendalian intern bersamasama memiliki pengaruh yang signifikan terhadap Laporan Keuangan.

Dari hasil penelitian diperoleh pengaruh secara simultan dari sumber daya manusia dan sistem pengendalian intern terhadap kualitas informasi laporan keuangan di Kabupaten Muna Barat hal ini terjadi karena pegawai di bagian keuangan memiliki kesadaran tinggi bahwa kepedulian dan kerja individu dapat melaksanakankualitas informasi keuangan dengan baik. 
Jurnal Akuntansi dan Keuangan (JAK)

Volume 6, No. 2 Oktober Tahun 2021

Page: 257 - 269

http://ojs.uho.ac.id/index.php/jak-uho/issue/archive

e-ISSN: 2088-4656

Hasil penelitian ini sejal dengan penelitian Sukma ninggrum dan Harto (2011), Mahaputra dan Putra (2014), dan Ratnaningsih (2017), menemukan bahwa sumber daya manusia dan pengendalian intern berpengaruh positif dan signifikan terhadap kualitas informasi keuangan.

\section{KESIMPULAN, IMPILIKASI, KETERBTASAN DAN REKOMENDASI Kesimpulan}

1. Sumber daya manusia berpengaruh positif dan signifikan terhadap kualitas informasi keuangan. Hasil pengujian membuktikan bahwa semakin tinggi kopetensi sumber daya manusia maka kualitas laporan keuangan semakin meningkat pada Pemerintah Daerah Kabupaten Muna Barat.

2. Pengendalian intern berpengaruh positif dan signifikan terhadap kualitas informasi keuangan. Hasil pengujian membuktikan bahwa semakin baik pengendalian intern maka kualitas laporan keuangan semakin meningkat pada Pemerintah Daerah Kabupaten Muna Barat.

3. Sumber daya manusia dan pengendalian internber pengaruh positif dan signifikan terhadap kualitas informasi keuangan. Hasil pengujian membuktikan bahwa semakin tinggi kopetensi sumber daya manusia dan semakin baik pengendalian intern maka kualitas informasi keuangan semakin meningkat pada Pemerintah Daerah Kabupaten Muna Barat.

\section{Implikasi}

Berdasarkan hasil penelitian tersebut maka diharapkan penelitian ini dapat memberikan masukan terhadap pemerintah Kabuaten Muna Barat untuk tetap meningkatkan kualitas laporan keuangan .

\section{Keterbatasan penelitian}

1. Ruang lingkup penelitian ini masih terbatas pada OPD di pemerintah Kabupten muna barat, diharapkan peneliti selanjutnya memperluas objek penelitian kelingkup yang lebih luas (pemerintah propinsi) atau lingkup di daerah lain yang berbeda karateristiknya agar dapat mendapatkan hasil yang lebih komperensif sehingga dapat dijadikan gambaran atau pembanding terhadap kesuksesan kulitas laporan keuangan antara satu tempat dengan tempat lainnya.

2. Penelitian ini hanya berfokus pada tiga variabel diharapkan peneliti selanjutnya dapat menambah variabel lainnya yang berpengaruh pada kualitas laporan keuangan.

\section{Rekomendasi}

Berdasarkan pembahasan dan kesimpulan yang telah diuraikan sebelumnya, maka peneliti dalam hal ini memberikan saran Bagi pemerintah Daerah Kabupaten Muna Barat agar selalu menjaga kopetensi tenaga kerja sumber daya manusianya dan selalu merangsang kemampuan mereka terutama dari segi pengetahuan, keterampilan dan sikap. Karena untuk mewujudkan laporan keuangan yang berkualitas diperlukan 
Jurnal Akuntansi dan Keuangan (JAK)

Volume 6, No. 2 Oktober Tahun 2021

Page: 257 - 269

http://ojs.uho.ac.id/index.php/jak-uho/issue/archive

e-ISSN: 2088-4656

tenaga pemikir, perencanaan dan penggerak yaitu sumber daya manusia yang berkopeten.

\section{DAFTAR PUSTAKA}

Afrianti, Dita. 2011. Analisis Faktor-Faktor Yang Mempengaruhi Nilai Informasi Pelaporan Keuangan Pemerintah Daerah (Studi Satuan Kerja Perangkat Daerah di Kabupaten Batang). Skripsi. Universitas Diponegoro.

Djalil, Rizal. 2014. Akunttabilitas Keuangan Daerah, Implementasi Pasca Reformasi. Jakarta : RMBOOKS.

Fadel, Muhammad. 2009. Reinventing Local Government: Pengalaman dari Daerah. Jakarta: Gramedia.

Lillrank, Paul. 2003. The quality of information. International Journal of Quality \&Reliability Management Vol. 20 No. 6 pp. 691-703.

Mainardes,E W., Alves, H., \& Raposo, M.(2011). Stakeholder Theory:Issues to resolve. Management Decision, 266-241.

Mustopadidjadja. 2002. Manajemen Proses Kebijakan Publik, Formulasi, Implementasi dan Evaluasi Kinerja. Jakarta: Lan.

Pengaruh Kapasitas Sumber Daya Manusia dan Sistem Pengendalian Intern terhadap Kualitas Informasi Laporan Keuangan Pemerintah Daerah (Studi pada Pemerintah Daerah Kabupaten Bantul). Skiripsi.

Sukmaningrum, Tantriani. Analisis Faktor-Faktor yang Mempengaruhi Kualitas Informasi Laporan Keuangan Pemerintah Daerah (Studi Empiris pada Pemerintah Kabupaten dan Kota Semarang), Skripsi, jurusan Akuntansi, Fakultas Ekonomika, Universitas Diponegoro, 2012.

Sutrisno, Edy. 2009 Manajemen Sumber Daya Manusia. Surabaya: kencana.

Staubus, 2000.The Decision-Usefulnes Theory of Accounting: A Limited History. New York and London:Granland Publishing, Inc.

Sugiono.(2010). Statistika untuk Penelitian. Bandung: Alfabeta.

Sugiyono. 2017. Metode Penelitian Bisnis pendekatan Kuantitatif, Kualitatif, kombinasi dan $R \& D$, Bandung : Alfabeta.

Suwanda, Dadang. 2015. Factors Affecting Quality of Local Goverment Financial Statements to Get Unqualified Opinium (WTP) of Audit Board of the Republic of Indonesia (BPK). ISSN 2222-1697 (paper) ISSN 2222-2847 (Online), Vol. 6 No. 4, 2015.

Uma Sekaran. 2009. Metode Penelitian Untuk Bisnis, Salemba Empat: jakarta.

Weygandt, J.J., et al. (2005). Accounting principles. New York: John Wiley \& Sons.s 